Asian J. Med. Biol. Res. 2016, 2 (4), 488-507; doi: 10.3329/ajmbr.v2i4.30988

\author{
Asian Journal of \\ Medical and Biological Research \\ ISSN 2411-4472 (Print) 2412-5571 (Online) \\ www.ebupress.com/journal/ajmbr
}

Review

\title{
Sundarban mangroves: diversity, ecosystem services and climate change impacts
}

Sucharit Basu Neogi ${ }^{1,2,3^{*}}$, Mouri Dey $^{4}$, S. M. Lutful Kabir ${ }^{5}$, Syed Jahangir H. Masum ${ }^{1}$, German Kopprio ${ }^{3,6}$, Shinji Yamasaki ${ }^{2}$ and Rubén Lara ${ }^{6}$

${ }^{1}$ Coastal Development Partnership, House No \# 181/A, Road \# 3, South Pirerbagh, Mirpur, Dhaka-1216, Bangladesh

${ }^{2}$ Graduate School of Life and Environmental Sciences, Osaka Prefecture University, Izumisano, Osaka 5988531, Japan

${ }^{3}$ Leibniz Center for Tropical Marine Ecology GmbH, Fahrenheitstr. 6, 28359 Bremen, Germany

${ }^{4}$ Department of Accounting and Information System, University of Chittagong, Bangladesh

${ }^{5}$ Department of Microbiology and Hygiene, Bangladesh Agricultural University, Mymensingh-2202, Bangladesh

${ }^{6}$ Argentine Institute of Oceanography, 8000 Bahía Blanca, Argentina

*Corresponding author: Dr. Sucharit Basu Neogi, Coastal Development Partnership, House 181/A, Road 3, South Pirerbagh, Mirpur, Dhaka-1216, Bangladesh; Phone: +88-01723053848; E-mail: sbneogi@yahoo.com

Received: 31 July 2016/Accepted: 10 August 2016/ Published: 29 December 2016

\begin{abstract}
The Bengal delta coast harboring the famous Sundarban mangroves is extremely vulnerable to climate change. Already, salinity intrusion, increasing cyclones and anomalies in rainfall, and temperature, are causing many social and livelihood problems. However, our knowledge on the diversified climate change impacts on Sundarban ecosystems services, providing immense benefits, including foods, shelters, livelihood, and health amenities, is very limited. Therefore, this article has systematically reviewed the major functional aspects, and highlights on biodiversity, ecosystem dynamics, and services of the Sunderban mangroves, with respect to variations in climatic factors. The mangrove ecosystems are highly productive in terms of forest biomass, and nutrient contribution, especially through detritus-based food webs, to support rich biodiversity in the wetlands and adjacent estuaries. Sundarban mangroves also play vital role in atmospheric $\mathrm{CO}_{2}$ sequestration, sediment trapping and nutrient recycling. Sea level rise will engulf a huge portion of the mangroves, while the associated salinity increase is posing immense threats to biodiversity and economic losses. Climate-mediated changes in riverine discharge, tides, temperature, rainfall and evaporation will determine the wetland nutrient variations, influencing the physiological and ecological processes, thus biodiversity and productivity of Sundarban mangroves. Hydrological changes in wetland ecosystems through increased salinity and cyclones will lower the food security, and also induce human vulnerabilities to waterborne diseases. Scientific investigations producing high resolution data to identify Sundarban's multidimensional vulnerabilities to various climatic regimes are essential. Sustainable plans and actions are required integrating conservation and climate change adaptation strategies, including promotion of alternative livelihoods. Thus, interdisciplinary approaches are required to address the future climatic disasters, and better protection of invaluable ecosystem services of the Sunderban mangroves.
\end{abstract}

Keywords: climate change; mangroves; wetlands; biodiversity; ecosystem services; livelihoods

\section{Introduction}

Mangrove ecosystems are governed by climate mediated physical forces, with dominant roles of tidal amplitude and duration, and quantity of freshwater inflow. Global warming is expected to cause changes such as higher temperatures, sea level rise and changing rainfall patterns, as well as more abrupt effects, such as an increase in the intensity and frequency of extreme events such as floods, storm surges, cyclones and sea level rise. Natural 
calamities like cyclone, flood, storms, coastal erosion, extreme rainfall and temperature, hydrological alterations, sea level rise, and salinity intrusion may drastically cause enormous devastations to flora and fauna of the mangrove ecosystems. The Sundarban, the world's largest uninterrupted mangrove forests, are particularly critical and highly fragile to climate change impacts because of its complex geo-morphology and environmental settings, and gradual shrinking under the rising sea (Lara et al., 2011). Although we are aware about anthropogenic over-extraction of resources beyond sustainable levels, attributable to poor resource management strategies and insufficient conservation measures, less is known about the salient influences of increasing natural disasters due to global warming and related climate change impacts on the ecosystem services of the Sunderban mangroves.

Mangroves are the salt tolerant evergreen forests which occur along the coastlines, estuaries, rivers or deltas. The Sundarban mangroves are shared between Bangladesh and West Bengal, India, comprising $6,017 \mathrm{~km}^{2}$ $(62 \%)$ and $4,246 \mathrm{~km}^{2}(38 \%)$, respectively (Mitra and Banerjee, 2004). The wetlands comprise of a network of mudflats and islands intersected by an elaborate network of rivers, channels and creeks with varying width and length. The Sundarban ecosystems experience tropical climate (estuarine water temperature $20-35{ }^{\circ} \mathrm{C}$ ), and monsoon wind influences with annual rainfall of 1500-2000 mm (Rahman and Asaduzzaman, 2010). The mangrove forests are well-flourished due to the location $\left(21^{\circ} 32^{\prime}\right.$ to $22^{\circ} 40^{\prime} \mathrm{N}$ and $88^{\circ} 05^{\prime}$ to $\left.89^{\circ} 51^{\prime} \mathrm{E}\right)$ in extensive intertidal areas of the Bengal delta receiving abundant freshwater supply through river discharges. The gentle slope of the low lying coast, with tidal water reaching up to $110 \mathrm{~km}$ inland, has facilitated the mangrove expansion (Spalding et al., 2010).

Being situated in the transition zone between land and the sea, mangroves have developed mechanisms to import, retain and export of organic and inorganic substances including nutrients. The Sundarban ecosystems are considered vital sources and sinks of carbon, with a huge amount of primary production from forests and wetlands, and also storing as particulate and dissolved organic carbon within organic peat soils, and through tide-mediated translocation to the nearby coastal waters, ultimately sinking as bottom sediments of the ocean (Kristensen et al., 2008). Sundarban mangroves are regarded as highly productive, and especially, the detritusbased food web contributes huge quantities of nutrients to supporting both native and adjacent coastal ecosystems (Manna et al., 2010). Considering the richness in both floral and faunal species abundance and diversity, the mangrove forests and wetlands of Sundarban have been declared as 'World Heritage' by UNESCO in 1999. The mangrove ecosystems are capable of producing rich natural resources, including foods, fuel woods, construction materials, and medicinal herbs, and also provide diverse environmental services, which invaluably support the local economy and poverty alleviation. More than 5 million people of India and Bangladesh residing in the peripheral regions of Sundarban are dependent for their livelihoods, based on the mangroves resources. Sundarban wetlands provide refuge for feeding, growing, and breeding to many marine organisms including commercially important shrimps and fishes, many of which later migrate to adjacent coastal waters or to the ocean. There are also non-material benefits, such as spiritual or aesthetic, that are provided by the Sundarban ecosystems. The immensely valuable natural resources and associated ecosystem services of Sundarban are, however, under alarming and chronic threats of deterioration due to the increasing extremities in climatic conditions.

The coastal regions of the Bengal delta are among the most vulnerable regions in the world experiencing rapid salinity intrusion and other climate change impacts (IPCC, 2007). The ongoing climatic changes, compounded with anthropogenic pressures, may cause multiple alterations in the mangrove flora, fauna, and wetland dynamics and functions bringing a lot of changes in its ecosystem services, providing enormous vital benefits to human livelihood and health. While the continuous increase of atmospheric $\mathrm{CO}_{2}$ is posing a challenging threat to the global climate, it is highly important to conserve and sustainably manage the Sundarban ecosystems, which act as important sink or source for organic carbon. Unless proper adaptation strategies are implemented, the climate change associated environmental changes will probably cause severe multidimensional impacts to our eco-socio-economic conditions, influencing coastal habitats, amenities and health. Hence, intensification of scientific studies on climate change should be conducted, taking into account vulnerabilities of the different spatiotemporal situations in high resolution, and proper knowledge on climate change impacts is very important, particularly for the vulnerable regions like the Sundarban ecosystems. This article aims to reveal the major functional aspects of the Sunderban mangroves with respect to the variations in climatic factors. For better understanding of the impacts of climate change on Sundarban, particular highlights on the biodiversity, habitat variations, and different ecosystem services of the forest and wetland ecosystems have been also included in this review. 


\section{Diversity of the Sundarban mangrove wetlands}

\subsection{Biodiversity}

The Sundarban world heritage is endowed with high biodiversity of aquatic and terrestrial flora and fauna. Of the 50 true mangrove plant species recorded throughout the globe, the Sundarbans alone contain 35 species, with dominance of Sundry (Heritiera fomes), followed by Gewa (Excoecaria agallocha). Several species are endemic such as Aegialitis rotundifolia, H. fomes, Sonneratia apetala, and S. griffithii. A total 334 plant species, 165 algal, 13 orchids, 17 fern, 87 monocotyledon, 230 dicotyledon, including 35 legumes, 29 grasses, 19 sedges, and 18 euphorbias, have been discovered from the Sundarban regions (Rahman and Asaduzzaman, 2008). The mangroves are also associated with flowering plants, palms, ferns, bryophytes, fungi, algae, lichens and bacteria. Bacteria are the most abundant organisms in the estuary, averaging between $10^{6}$ to $10^{7}$ per ml organisms in water and $10^{8}$ to $10^{10}$ per gram dry weight of sediment (Lara et al., 2011). Phytoplankton community was observed to be dominated by diatoms (Bacillariophyceae) followed by Pyrrophyceae (Dinoflagellates) and Chlorophyceae. A total of 46 taxa belonging to 6 groups including the above dominants, and also Cyanophyceae, Euglenophyceae and Chrysophyceae have been recorded (Manna et al., 2010). The faunal biodiversity of Sundarbans includes 215 species of fishes, 7 species amphibian, 59 reptiles, more than 200 birds, 39 mammals, in addition to numerous species of phytoplankton or algae (>100 species), zooplankton ( $>100$ species), and invertebrates including insects ( $>300$ species), brachyuran crabs (26 species), polychaetes (69 species), molluscs (110 species), and micro-arthropods (44 species) (Chakraborty, 2011). The wetlands not only host large populations of economically important crabs, molluscs, shrimps (20 species), lobsters (8 species) and fishes, but also act as vital nursery grounds and natural sources for shrimp larvae meeting the demand of increasing aquacultures, and 120 species of commercially important fishes harvested by the fisherman. Among the magnificent wild animals the world famous Royal Bengal Tiger, spotted deer, barking deer, wild boars, jungle cats, civet cat, monkey, bengal fox, jackle, many beautiful birds, including heron, stork, erget, pheasant, wood pecker, bee-eater, myna, etc., lizards, dolphins and snakes are important faunal spp (Rahman and Asaduzzaman, 2008).

\subsection{Diversity in habitats}

The major ecosystems of the Sundarban include mudflats, sand beaches, coastal dunes, estuarine networks, shallow creeks and mangrove swamps. Habitat-wise, the Sunderban ecosystems can be broadly categorized into a) mangrove swamps, b) riverine /tidal wetlands, c) agroecosystems, and d) upland/ upstream and low-land /downstream forests. The Bengal Basin deltaic regions of Sundarban have been gradually tilting towards east (Morgan and McIntire, 1959). This has probably caused the main fresh water discharge to shift gradually eastward. In accordance to the variation in the environmental conditions, like salinity, species zonations, particularly due to the succession of mangrove trees from sea towards inland as well as from east to west, are evident. Variations in rainfall and riverine input, in combination with topographic differences including tectonic uplift in the west, are causes of salinity differences, with formation of hypersaline environment in the low-lying central part, and comparatively low saline conditions of the soil in the comparatively elevated regions of the eastern and western parts (Hanebuth et al., 2013).

Among the typical mangrove trees, Avicennia marina, A. alba and Bruguiera cylindrica grow in the downstream regions near the shoreline, while Bruguiera sexangula, B. gymnorhiza, Ceriops decandra and Rhizophora mucronata dominate in the central and upstream swamps. In the upstream region nearby the riverine channels certain mangrove species, which cannot withstand relatively high salinity for long time, e.g., $E$. agallocha, H. fomes, Sonneratia apectala, and S. caseolaris are more common, and flourishing more in the eastern part (Rahman and Asaduzzaman, 2008). Mangroves' soil consists mainly of silt, clay and fine fibrous roots, organic matter may constitute $>20 \%$ of dry weight (Thong et al., 1993), and only a thin upper portion of it is aerobic. Turnover of nutrients in mangroves heavily depends on the soil type, its oxic and anoxic condition, which in turn depend on tidal inundation regime. However, Avicennia rhizospheres can change the soil environment independent of tidal influence and can translocate oxygen through roots into surrounding soils (Thibodeau and Nickerson, 1986). High soil salinity limits tree density and height, and litterfall influencing primary production and flow of carbon. The litterfall rates have high range of variability (approx. $5 \mathrm{tha}^{-1} \mathrm{yr}^{-1}$ to $30 \mathrm{t} \mathrm{ha}^{-1} \mathrm{yr}^{-1}$ ), depending on forest type and settings, and the rate is higher in the riverine regions (Silva et al., 1998a). Moreover, settlement of some mesophytic bioinvasive plant species has enhanced ecological instability manifold of this sensitive eco-region forcing some other plant species such as S. apetala, Avicenia alba and Acanthus ilicifolius to experience landward movement (Chakraborty et al., 2009). 
3. Key functional aspects and ecosystem services of the mangroves

\subsection{Root system}

One of the important functions of mangroves is sediment trapping by their complex aerial root systems, and thus acting as sinks to the suspended sediments and associated organic matters, to aid in coastal land expansion (Twilley et al., 1992). Water velocity within the creek often exceed $1 \mathrm{~m} \mathrm{~s}^{-1}$, while within swamp (large area) it rarely reach $0.1 \mathrm{~m} \mathrm{~s}^{-1}$ due to the frictions from the bed and mangrove roots. The density of prop roots and pneumatophores in a tidally driven mangrove wetland is most important in determining whether the system is eroding or accreting. Mangrove roots are also ideal places for active nutrient turnover. Nitrogen transformation (ammonification, denitrification, nitrification) or nitrogen fixation rate by bacteria are greater in mangrove soils with more plants than soils without plants, including the root system (Routray et al., 1996). Also, higher rates of bacterial sulfate reduction coincide with the presence of underground mangrove root systems (Kristensen et al., 1991). Calcium phosphate is the dominant form of phosphorus in below ground roots, whilst litterfall turnover plays vital role in phosphorus dynamics as the nutrient is mainly stored in mangrove leaves (Silva et al., 1998b). Inorganic carbon in mangrove sediments is mostly found as $\mathrm{FeCO}_{3}$ and mangrove rhizospheres are active sites for iron precipitation (Alongi et al., 2001).

\subsection{Allochthonous input and trapping of nutrients}

Being a river-influenced mangrove system, the Sundarban is characterized by high influx and strong out-welling of nutrients, which play a vital role on fishery productions in the adjacent coastal waters. During the monsoon, the estuarine regime of Sundarban is influenced by the interaction of the riverine discharge and the tides, which together enhance the seaward drift of the sediments, while during the dry period, with reduced freshwater input, strong tidal currents govern the estuary facilitating the upstream drift of suspended sediments in the wetlands (Rahman and Asaduzzaman, 2008). Sediments in many mangroves are highly traversed by numerous crab holes, making the mangrove soil highly porous, which also facilitate material exchange through tidal water movement. Phosphate, nitrate, and dissolved organic carbon (DOC) in groundwater may become highly concentrated compared to creek water at low tide and during dry season (Lara and Dittmar, 1999). Mixing of surface and ground water is an important buffer mechanism for nutrient exchange between coastal and mangrove waters. Groundwater is recharged by downward infiltration, a process facilitated by high number of crab holes, during receding peak of flood tide. Nutrient trapping in pore water can result in reduction of tidal export, hence, ground water flows and fluctuations can influence the total nutrient export from the mangrove (Ovalle et al., 1990).

\subsection{Biomass and litter production}

Mangroves contribute significantly to the global carbon cycle, with an important contribution of litter fall derived organic matter, and globally the estimated mangroves litter fall varies from 130 to $1870 \mathrm{~g} \mathrm{~m}^{-2} \mathrm{y}^{-1}$ (Twilley et al., 1997). In the mangroves of coastal region in Bengal delta, Avicennia spp. litter production is high in the post-monsoon and low in the pre-monsoon periods. Litter from the mangroves is composed of leaves, twigs, branches and seeds. Seeds alone may account for about $25 \%$ of the total litter fall for Avicennia spp. in mangrove habitats (Chowdury et al., 2011). Accumulated mangrove litter may wash into rivers and streams when rain or tides inundate the forest. Sundarban mangroves estuaries are one of the largest detritusbased ecosystems in the world where mangrove litters, providing a bulk portion of the detritus and nutrients, and playing an important regulatory role for the productivity of adjacent Ganges-Brahmaputra estuarine complex, which act as an important nursery ground for many commercially important shell and fin fishes.

\subsection{Carbon and nitrogen fixation}

Mangroves are second only to tropical rain forests in term of primary production (average $2.5 \mathrm{~g} \mathrm{C} \mathrm{m}^{-2} \mathrm{~d}^{-1}$ ). Majority of photosynthetic carbon fixation occurs in the canopies. Epiphytic macroalgae on prop roots can equal annual litterfall of the fringing forest and have high aerial carbon fixation rate $\left(>2.7 \mathrm{~g} \mathrm{C} / \mathrm{m}^{2} /\right.$ day) (Dawes et al., 1999). Seasonal plankton blooms can also be a major source of autochthonous production of organic carbon. In relatively less turbid shallow waters, phytoplankton can constitute $50 \%$ of total carbon fixed per day in comparison to $43 \%$ in mangrove swamps (Day et al., 1982). High turbidity, flactuations in salinity and relatively small ratio of open water to mangrove forest contribute to lower primary production (20\%) by phytoplankton (Robertson et al., 1992).

To compensate the low nitrogen content in soil and loss of nitrogen through denitrification, nitrogen fixation by certain microbes present in sediments, decomposing leaves, pneumatophores, rhizosphere soil, tree bark and cyanobacterial mats, is generally high in mangroves, especially in, compensating $>40 \%$ of annual nitrogen 
requirement of the swamp forests and wetland ecosystems (Sengupta and Chaudhuri, 1991). Photosynthetic nitrogen fixation is commonly carried out by cyanobacteria or by photosynthetic bacteria, e.g., purple sulfur bacteria. However, the fixation rate can be low in soil sediments and rhizospheres if high concentration of soluble nitrogen is present in water (van der Valk and Attiwill, 1984).

\subsection{Recycling of nutrients}

To adjust with the very unstable environment, many mangrove trees have developed re-translocation and resorption of nutrients prior to shedding of their leaves. Recycling of organic matter is important in fulfilling the high nutrient demand of highly productive mangrove systems. Nitrogen re-translocation and storage is associated with litter dynamics as substantial amounts of nitrogen are preserved in the canopy and long-lived leaves. Microorganisms, especially associated with root systems, have also the ability to nutrient regeneration or mineralization of organic compound. Crabs, insects and other animals, who consume huge amount of mangrove vegetation, also play considerable role by enrichment via excretion. Mud crabs can contribute majority (>60\%) of the nitrogen required for primary production by burial of litters, although this transformation yield may be low $(<10 \%)$, depending on tree species and spatio-temporal variations. Thus, the patterns of material recycling in particular mangrove localities invariably influence the regional productivity (Robertson et al., 1992).

\subsection{Microbial transfer and turnover of nutrients by microorganisms}

Microbes play a vital role in nutrient recycling in a mangrove system and contribute to its high productivity. Among them bacteria and fungi constitute the bulk (>90\%), whereas algae and protozoa are represent the rest minor portion. Sediment bacteria in mangroves consume DOC, thus play important role in export of DOC to nearby coastal waters (Alongi et al., 2001). Nitrogen is generally utilized by bacterial conversion of soil nitrates, derived from nitrogenous organic compounds, into ammonium which can be assimilated by both plants and bacteria. Rapid decomposition rate of fallen litters increases the availability of nutrients for re-absorption by roots and prevent the loss of nitrogenous compounds (Rivera-Monroy et al., 1995). Phosphate soluble bacteria in the root system, depending on root oxygen translocation rate, also play potential role in supplying soluble form of phosphorus to plants (Vazquez et al., 2000). In the vast anaerobic zone of mangrove sediments, decomposition of organic matter is accomplished mainly through sulfate-reduction. Photosynthetic anoxygenic bacteria fix a large portion of carbon within sulphur-rich sediments through utilization of $\mathrm{H}_{2} \mathrm{~S}$ instead of $\mathrm{H}_{2} \mathrm{O}$ as electron donor. Sulfate reducing bacteria, which are also among the most numerous bacterial groups $\left(10^{6} \mathrm{CFU}\right.$ $\left.\mathrm{g}^{-1}\right)$ in mangrove root systems (rhizospheres) utilize soluble sulphur to react with iron complex $\left(\mathrm{FeOOH}-\mathrm{PO}_{4}\right)$ producing pyrite $\left(\mathrm{FeS}_{2}\right)$ and releasing soluble phosphate, thus play important role in the production of soluble iron and phosphorus (Sherman et al., 1998).

\subsection{Exchange with the atmosphere}

Gaseous exchange of carbon between mangrove systems and the atmosphere is very important and depends on the biochemical phases of different physiological reactions. During respiration of the flora and fauna of the mangroves a large portion of $\mathrm{CO}_{2}$ is expelled to the atmosphere. However, benthic respiration also acts as the other major process facilitating the organic carbon expulsion from mangrove ecosystems, and most of the total $\mathrm{CO}_{2}$ release from the sediment is mediated by microbial sulfate reduction (Alongi et al., 1998). On the other hand, nitrogen is generally transferred to the atmosphere as gaseous nitrous oxide $\left(\mathrm{N}_{2} \mathrm{O}\right)$, a by-product of both denitrification and nitrification. Denitrification is a sub-oxic process within mangrove sediments, while nitrification-derived $\mathrm{N}_{2} \mathrm{O}$ is produced in aerobic regions. Comparison of phytoplankton production to community respiration has indicated the heterotrophic nature of the Sundarban ecosystems. The saturation of dissolved carbon dioxide in the creek surface water with respect to the atmosphere has been shown to fluctuate seasonally, between 59\% and 156\%, with minimum and maximum levels during post- and pre-monsoon, respectfully (Manna et al., 2012).

\subsection{Exchange with the coastal ocean and carbon sinking}

Leaf litters are the major source of carbon in mangrove ecosystems. Organic detritus is exported to nearby coastal waters both as particulate and dissolved forms. A bulk of primary production can be transported as particulate organic matter, and the organic carbon export is dependent on tidal force among different mangrove habitats. Tides facilitate export of more than $80 \%$ of leaf fall when amplitude is greater than $2 \mathrm{~m}$ (Twilley, 1998). Nutrient exchange rates vary in different parts of the mangrove creeks, and are more rapid in vegetated banks (>90\% of nitrogen flux, Davis et al., 2001). In comparison to the terrestrial forests, mangroves are more efficient sinks for atmospheric carbon, sequestering four times carbon per unit area (Khan et al. 2007). 
Exchange of organic compounds (with carbon, nitrogen etc.) between mangrove wetlands and nearby estuaries is predominantly mediated as dissolved form, e.g., in case of Avicennia forests, $>90 \%$ of total organic carbon, and the magnitude of the DOC flow from mangrove ecosystem to the offshore invariably depends on the decay of particulate organic carbon (POC) in inter-tidal mangrove zones (Davis et al., 2001). Mangrove originated dissolved organic matter greatly contributes in the secondary production of nearby estuaries and most of the expelled DOC and DON can rapidly be utilised by microfauna and macrofauna present in estuaries (Camilleri and Ribi, 1986). However, a major portion of mangrove detritus including DOC has been reported to be refractory to biological assimilation, and thus included in carbon sinking (Alongi et al., 1993).

\subsection{Food chain and energy transfer to higher trophic levels}

In the mangrove ecosystems, the plants and other primary producers (algae) convert energy into living biological materials. Leaf litters are the major source of carbon in mangrove forests on the swamp ecosystems. Food and energy are consumed through sequential transfer into organisms of higher trophic levels, while at each stage of this food chain, some energy is excreted as waste, or converted into body growth or heat after respiration and also during reproduction. Phytoplankton are the primary sources of foods or energy in the mangrove wetlands, initiating the food-chain which may culminate in large harbivorus and carnivorous fishes and also to terrestrial birds and mammals. Detritus feeders, plant grazers, and zooplankton are the primary consumers, and the secondary and tertiary consumers include estuarine birds, ducks, invertebrate predators, and fish. Excreta and detritus pass to the decomposer tropic level where microorganisms break down the material. In case of mangrove dominated Sunderban estuaries, where huge quantities of leaf litters are loaded to the adjacent estuarine water, the availability of nitrogen is considered as a major limiting factor in determining overall productivity and heterotrophic bacterial production may exceed phytoplankton primary production (Manna et al., 2012). Community respiration rate provides a estimate of heterotrophic activity that can be directly related to the oxidation of organic matter and it is regarded as a key index of the energy used by consumers at a given time and place (Biddanda et al., 1994). Sunderbans estuary is designated as a moderately productive estuary with an annual integrated phytoplankton production rate ranging 3.0 to $6.0 \mu \mathrm{g} \mathrm{C} \mathrm{L}^{-1} \mathrm{~h}^{-1}$ and community respiration ranging 1.5 to $3.5 \mu \mathrm{g} \mathrm{C} \mathrm{L}^{-1} \mathrm{~h}^{-1}$ (Manna et al., 2012). Mangrove-derived detritus is the dominant energy source serving major portions of the diets of and many organisms including crustaceans, oysters, mussels, insect larvae, nematodes, polychaetes, and fishes in the estuarine wetlands of the Sundarban mangroves. Active microbial transformation of detritus facilitates the channelling of essential nutrient elements from lower organisms (protozoa and metazoa) and subsequently to organisms of higher trophic levels (Bano et al., 1997).

\subsection{Grazing and decomposition of mangrove litter and detritus}

Mangrove ecosystems, characterized with high rate of leaf fall, produce large amounts of litter in the form of falling leaves, branches and other debris. Large scale grazing of the vegetative parts of mangroves by various animals, especially crabs and insects, influences the system functions of the swamps and wetlands ecosystems. Crabs can consume huge amount of leaves or carry them down their burrows. Field experiments have observed the extremely swift capacity of crabs grazing, macerating most of the mangrove litters within an hour, which can be facilitated by co-participation of amphipod like small grazers, turning larger foods into small particles, thus increasing the surface area for microbial colonization and decomposition (Twilley et al., 1997). Intense bioturbation by mud crabs allow oxygenation into the sediments. Besides, crabs can consume mangrove seeds to a large scale affecting its dispersal. Insect herbivores can remove $>35 \%$ of leaf areas and teredinid molluscs (shipworms) can ingest $>90 \%$ of decomposing trunks (Robertson, 1991).

Mangrove's vegetative parts, i.e., mostly lignin and cellulose derivatives, are difficult to convert into simple forms but can be degraded by microorganisms into water-soluble compounds. Bacteria, autochthonous to mangrove ecosystems, can readily assimilate the leachable components, particularly in the aerobic conditions, and this utilization rate is manifold (>18x) higher than that of planktonic microflora (Benner et al., 1986). Fungi can tolerate high levels of phenolic compounds of mangrove leaves that inhibit growth of other microbes, and fungal decomposition of non-leachable compounds is facilitated by their secreted enzymes capable of degrading pectin, protein, starch, cellulose and lignin. Afterwards, secondary colonization of bacteria and fungi initiates further decomposition with similar enzymatic activities (Raghukumar et al., 1995).

Decomposition of mangrove detritus is initiated as leaching of soluble materials, mostly in the form of carbohydrates and other dissolved organic matter (DOM). The leechable organic matters, comprising nutrients, are recycled both in the mangrove area and in adjacent habitats through hydrological processes. The weight loss of different classes of leaves and non-leaf litters varies from 40 to $80 \%$, as partial decomposition rate was found 
to be slower for non-leaf litters in Bangladesh Sundarbans (Haq et al., 2002). Nitrogen rich detritus materials become foods for the smaller animals such as worms, snails, shrimps, mollusks, mussels, barnacles, clams, and oysters. These detritus eaters then become foods for the carnivores, including crabs and fish, subsequently birds and game fish, following the food web, culminating in man.

\subsection{Ecosystem services}

Among the numerous ecosystem service components of the Sunderban mangrove ecosystems include but not limited to (I) goods to sustain livelihoods, e.g., foods and drinks, timbers, leaves (used to build house roofs and cooking fuel), fibre, medicinal components, cosmetic resources, and compounds used for renewable energy; (II) vital environmental services including primary production, replenishing gaseous oxygen, habitat provision supporting biodiversity, water transportation, nutrient cycling, pollination, genetic resources, preservation of organic components or signatures with the sinking sediments etc.; (III) invaluable regulating services, beneficial to human populations, including filtration of air pollutants, detoxification of water and sediments, erosion control, local climate regulation, protection from solar UV-B radiation and 'green house' effects, flood risk mitigation, protection from storms, acting as surface water reservoirs, groundwater replenishment, crop pest regulation, human and animal disease regulation, land reclamation and shore stabilization; and (IV) cultural services, e.g., spiritual and sectarian values, ornamental products, recreation and ecotourism (Walters et al., 2008).

Sundarban mangroves are highly valuable as sources of a variety of fruits and other natural foods, and also provide breeding grounds and nurseries for many edible fishes, shellfishes, and turtles. For the fisheries sectors, the Sundarban ecosystems have immense importance as the estuarine habitats serve as nursery, feeding and breeding grounds for many economically valuable fishes and shellfishes. The mangrove ecosystems harbour higher densities of juvenile fishes than adjacent estuarine and coastal regions. A large number of estuarine fishes use mangrove during juveniles due to their a) feeding requirements, b) active preferences for particular physical conditions reducing effectiveness of predators (e.g., turbidity) and c) structural complexity, increased shelter from predators provided by prop roots, pneumatophores, and fallen log and branches in mangrove forests and within debris in mangrove creeks (Robertson \& Duke, 1990). The catch of fishes, shrimps and prawns, crabs, molluscs, etc. contributes value to the small-scale fisheries. Various goods, mainly firewood, shells, honey, wax, tannins, and medicine, are frequently harvested from the mangrove ecosystems, which contribute to the value of the subsistence forestry sector (Sarker et al., 2010). The rich biodiversity of the Sundarban mangroves is highly attractive for recreational purposes and are invaluable in flourishing ecotourism. The endemic presence of the Royal Bengal Tiger, crocodiles, deer, monkeys, and migratory birds in these coastal mangroves invaluably contributes to ecotourism.

\section{Climate impacts on ecosystem dynamics, diversity and functions}

The influences and relationships of various climatic factors, e.g., sea level rise, rainfall and temperature anomalies, tidal fluctuation, etc., with the key physical, biogeochemical and biological factors of the mangrove wetland and forest swamp ecosystems, eventually impacting the diverse functional and beneficial services, have been schematically depicted in Figure 1. The major aspects and probable impacts of climate change impacts on the mangroves ecosystem functions and diversity, as reflected by the variable influences of individual key climatic factors, have been briefly described in the following sections.

\subsection{Tidal influences}

Sundarban mangroves are characterized by asymmetry between the ebb and flood tides, i.e., while circulating within the creeks, ebb tide being shorter in duration but with stronger currents than the flood tide. When the tide reaches high at the head of creek, it is already falling at the mouth, this provides necessary water slope to accelerate water back toward the mouth as the ebb phase commences. Stronger ebb current thus aid in maintaining tidal channels navigable. However, mangrove channels in the coastal downstream, with inter-tidal mud flats near the shoreline, usually become very shallow, where friction effects dominate, preventing the formation of ebb tidal jets at the mouth of creeks. During ebb tide the wetland discharged water enters the near shore region in low velocity, whilst during flood tide the strong waves often push back to re-enter into mangrove creek. Thus the nutrient rich mangrove water usually stays in near-shore for long time and mixes slowly with offshore water (Wolanski and Ridd, 1990).

The inundation of mangrove swamp at rising tide is unique as during initial stage the tidal waters come through numerous crab holes in the ground, and such mixing acts as important buffer mechanism preventing salt accumulation and facilitating nutrient exchange between coastal and mangrove waters (Ovalle et al., 1990). The 
balance between rainfall and evaporation, in conjunction with the tidal variations, is a key factor determining the vegetation and productivity in the mangrove swamp (Oliver, 1982). Input of nutrients from the floor of the mangrove swamp by tide or rainfall is a major source for nutrient increase in the creeks. Nutrient availability is the most vital feature that determines the swamp vegetation and primary production, but its availability is regulated by the spatio-temporal variation in tidal amplitude and may be higher in tidal creek during the neap than spring tides (Lara and Dittmar, 1999).

The semi-diurnal tidal fluctuations in the Sundarban mangrove indirectly facilitate the reduction of competition among different organisms, due to alternating wetting and drying, and also exporting wastes, detritus, and effectively dispersing mangrove propagules, aiding the forest growth and expansion. Export of litter from mangrove ecosystems is exclusively dependent on tidal amplitude, e.g., in case of high tidal amplitude as high as $70 \%$ of total leaf fall, and conversely, in case of low tidal amplitude only $7 \%$ of total leaf fall, produced between tides (Silva et al., 1998a). Moreover, an increase in tidal fluctuation has been correlated with the faster decomposition of mangrove detritus, facilitated by the increased microbial activities (Robertson et al., 1992). Interestingly, high resolution analysis of surface waters from tidal estuaries of the Bengal delta and riverine channels of the Sundarban mangroves have revealed conspicuous influences of water salinity and tidal phases, i.e., ebb and flood tides, on microbial population dynamics and diversity (Lara et al., 2009, 2011; Batabyal et al., 2014).

\subsection{Sea level rise and coastal erosions}

Mangroves grown in the low-lying coastal regions, like Sundarban in the Bengal delta, are particularly sensitive to the climate change mediated increase in sea surface height. If mangroves' land-ward propagation rate is lower than the habitat loss rate due to sea level rise (SLR), these important ecosystems are on the verge of severe degradation and may become extinct in many regions. SLR mediated alterations in mangrove habitats will invariably influence the nutrient flow and composition in coastal areas. The annual mean sea level near the Sundarban mangroves has risen steadily, e.g., during 1985 - 1998 more than $4 \mathrm{~mm}$, at a rate of $3.25 \mathrm{~mm}$ per year, which is significantly higher than average global sea level rise of $2 \mathrm{~mm}$ per year. On the other hand, the rate of coastal erosion, as measured for the Indian Sundarban mangroves, has been measured about $5.70 \mathrm{~km}^{2}$ per year within the time span of 1989 to 2014, showing more impacts to the south-western edges, particularly, 12 sea facing southern islands, including the 'Jambu' and 'Sagar' Islands (Ghosh et al., 2015). The conspicuously higher rate of SLR, affecting the Sundarban wetlands habitat loss, might be due to the regional low-lying topography, with very low slope and elevation only $0.9-2.1 \mathrm{~m}$ above mean sea level, compounded with high riverine discharge of water and sediments (Hussain and Acharya, 1994). The coastline retreat of about $3 \mathrm{~km}$ between 1968 and 2014 has already been observed for the southern islands, with a loss of $284 \mathrm{~km}^{2}$ within the last 50 years, whereas accretion being $84 \mathrm{~km}^{2}$ only (Ganguly et al., 2006). On the other hand, increase in riverbank erosion during 2000 - 2010 has instigated the formation of new marshy areas of about $6.0 \mathrm{~km}^{2}$ inside the comparatively low-saline upstream of the mangrove forests (Figure 2). Rising sea level, combined with coastal erosion, has caused submersion of two islands in the Sundarban, and a dozen more are under threat of submergence. According to the current prediction, the low salinity areas will be intruded further inland and probably become considerably reduced, causing massive shifts in the abundance and distribution of mangrove species in the Sunderban (Sams-Uddin et al., 2013). Sea level rise associated increase in salinity may diminish the low-salinity tolerant species and cause intrusion and flourish of halo-tolerant coastal species towards more inland, posing immense threats to biodiversity and economic losses.

\subsection{Temperature}

In the coastal region of the Bengal delta harbouring the Sundarban mangroves, sea surface temperatures have increased at a rate of approximately $0.05^{\circ} \mathrm{C} /$ year, which is much higher than the observed warming trends in the tropical Pacific Ocean $\left(0.01-0.015^{\circ} \mathrm{C} /\right.$ year $)$ or tropical Atlantic Ocean $\left(0.01-0.02{ }^{\circ} \mathrm{C} /\right.$ year $)$ (Mitra et al., 2009). Warmer temperature events since 1960s have been thought to greatly influence the phenology of organisms, the range and distribution of species, and the composition and dynamics of communities (Walters et al., 2008). Climate change mediated variations in temperature, will continue to affect at all levels of biological organisation, and physiological and ecological processes in many direct, indirect and complex ways. For the Sundarban ecosystems, increase in temperature has been observed to influence growth and development of the growing stock of the mangrove forests (Rahman and Asaduzzaman, 2010). Species diversity of phytoplankton in Sundarban wetlands is higher in summer (March) and lower in winter (November), indicating its close correlation with ambient summer temperature $\left(25-35{ }^{\circ} \mathrm{C}\right.$ ) (Manna et al., 2010). Climatic variations have 
detectable effects on fish distribution through changes in growth, survival, reproduction or responses to alterations at other trophic levels (Perry et al., 2005).

\subsection{Salinity}

Annually, the water salinity increases during the dry season and influences the seasonal variability of soil salinity, which is correlated with the variability of monsoon rainfall and river water discharge. Peak salinity level (20 to $30 \mathrm{ppt}$ in the downstream region) occurs in March-May and drops gradually in the soil and abruptly in water after June. Anthropogenic drivers, particularly some developmental infrastructures, e.g. construction of dams and large-scale shrimp farming in the upstream, have dramatically decreased the level of freshwater flow to the Sundarbans, facilitating the climate change induced salinity intrusion (Lara et al. 2011). More than double increase in the area of high salinity (>20 ppt) of sub-surface soil, extending beyond the Sundarban mangroves, has been recorded since 1973 and it is attributable to salinity intrusion in groundwater (Figure 2), although the top soil (upper $15 \mathrm{~cm}$ ) salinity is usually lower in the eastern part (1-18 ppt, Aziz and Paul, 2015). The upstream low salinity zone contains the highest ecosystem carbon stock $\left(336 \pm 15 \mathrm{Mg} \mathrm{C}^{-1}\right)$ followed by moderate and strong salinity zones. The regional differences of carbon stock the Sundarban has been related to salinity and dissolved nutrients (Wahid et al. 2007) and with increasing salinity the mangrove plants become dwarfed. The observed salinity intrusion in the Sunderban swamps may have far reaching consequences to its biodiversity, with likely decline in species richness. Increase in soil salinity in the Sundarban mangroves swamp has been related to the recent decrease in canopy closure, and increase in the prevalence of a top dying disease of economically important tree species Heritiera fomes (Aziz and Paul, 2015; Figure 2). However, biomass production in wetlands may increase during the dry period with higher salinity of water if the salinity regime is within the tolerance level of planktonic biomass (upto $15 \mathrm{ppt}$ ). Deterioration of desirable water quality due to salinity ingress, compounded with anthropogenic pollutants, may have substantial negative impacts on commercially important fish larvae, and the observed sharp decline in the harvest of commercially important fish species, especially in the central part of the Sundarban (Mitra and Banerjee 2011; Raha et al., 2012).

\subsection{Glacier melting, rainfall, and riverine input}

Himalayan glaciers are reported to be among the fastest retreating in the world due to the effects of global warming. Among the identified implications of global warming on glacier retreat in the Himalayas include, firstly, in the short run, more water will be available for the perennial rivers, which may generate positive effects in dry season; secondly, chances of glacial lake outburst floods (GLOFs) may increase putting downstream communities and river infrastructure at higher risk; thirdly, in the long run, dry season flows may reduce; and, fourthly, higher silt loads may result from the increased dry season flows in the short run, which can drastically reduce the lifespan of downstream reservoirs (IPCC, 2007). Climate change mediated enhance in glacier melting in the Himalayas has been related to the higher erosion rates over land accretion, as well as to the increase in riverine sediment discharge and deposition in the coastal regions within and nearby the Sundarban (Ghosh et al., 2015). The higher deposition of allochthonous sediments along the shallow tidal channels, particularly in the swamp region, may increasingly modify the inundation and salinity regimes, with change in species succession, ultimately influencing the food web and biodiversity in the predicted climate change scenarios.

In the Bengal delta, $>80 \%$ of annual rainfall occurs during the monsoon season from June to October. The mean annual rainfall in the Sundarban region varies from about $2000 \mathrm{~mm}$ in the east and $1600 \mathrm{~mm}$ in the west (Rahman and Asaduzzaman, 2010). Organic carbon and nutrient import rates show variations in response to seasonal fluctuations as well as the amount and occurrence of rainfall. A recent study on the Amazon forests encompassing mangrove wetlands has observed that intense precipitation anomalies are associated with lower growth of the trees, while the occurrence of drought can increase their mortality and cause less sequestration of atmospheric carbon by the forest and wetland ecosystems (Feldpausch et al., 2016). On the other hand, increased runoff mediated higher concentration of suspended sediments are correlated with higher turbidity with negative impact on photosynthetic activity of the phytoplankton, with reduction in overall productivity of the mangrove wetland ecosystems (Ghosh et al., 2015). Anomalies in seasonal rainfall, compounded with increase incidences of heat spells, may cause profound reduction in crop and fruit harvests in the Sundarban, with implications for coastal health and food security, as predicted for rain-fed agriculture due to climatic variations (Challinor et al., 2007).

The great hydrologic network comprising rivers, creeks and canals of Sundarban (in total 430 in Bangladesh part) facilitates the freshwater flow into the mangrove ecosystems (IWM, 2003). Nutrients and sediments from river water enrich mangrove soil, especially during flooding. Increase in riverine nutrient input, often with high 
suspended sediment load (exceeding $1,000 \mathrm{mg} \mathrm{l}^{-1}$ ), can contribute to increased tree height, high primary production and litterfall in the Sundarban ecosystems, as observed for mangroves in other continents (Day et al., 1987). Interestingly, in some parts of a mangrove system, nutrients like total organic carbon, dissolved inorganic nitrate (DIN) and dissolved inorganic phosphate (DIP) may be imported in one time and exported in other time of the same month resulting in rapid variations of nutrients (Davis et al., 2001). A conspicuous observation for some basin mangroves, including the Sundarban, is the strong correlation of rich vegetation in swamp forests with higher river input and rainfall driven lower salinity, resulting higher biomass and higher carbon stock during monsoon (Rahman et al., 2015).

\subsection{Cyclones and tidal surges}

On the Bay of Bengal along the Sundarbans the occurrences of cyclones increased by $26 \%$ between 1881 and 2001 (Singh, 2002). A projection modelling predicts a further increase in the frequency of cyclones, particularly in the late monsoon season, as well as a higher intensity of storms in the pre-monsoon months (May and June) between 2070 and 2100 with the possible outcomes for mangrove structure and functions (Unnikrishnan et al., 2011; Ghosh et al., 2015). During the appalling Indian Ocean Tsunami in 2004, which claimed the lives of more than 230,000 people in fourteen countries, the presence of Sundarban mangroves in the costal Bay of Bengal is thought to save hundreds of thousands of lives. Similar protective role of mangroves shielding the coastal communities from cyclones and tidal surges at the expense of loss of huge number of swamp flora has been known. In the recent decade, cyclonic storm "Sidr" in 2007 destroyed some 30,000 ha, comprising about onefourth, of Sundarban mangrove forests (Figure 2). Furthermore, in May 2009, much of the momentum of cyclone Aila was absorbed by the mangroves, saving the city of Kolkata and other urban sprawls in close vicinity (Shams-Uddin et al., 2013). However, following a sequence of recent severe disturbing events, with several cyclones in a row ('Sidr' in 2007, 'Nargis' in 2008 and 'Aila' in 2009), there is concern that the mangroves' regeneration ability has been weakened.

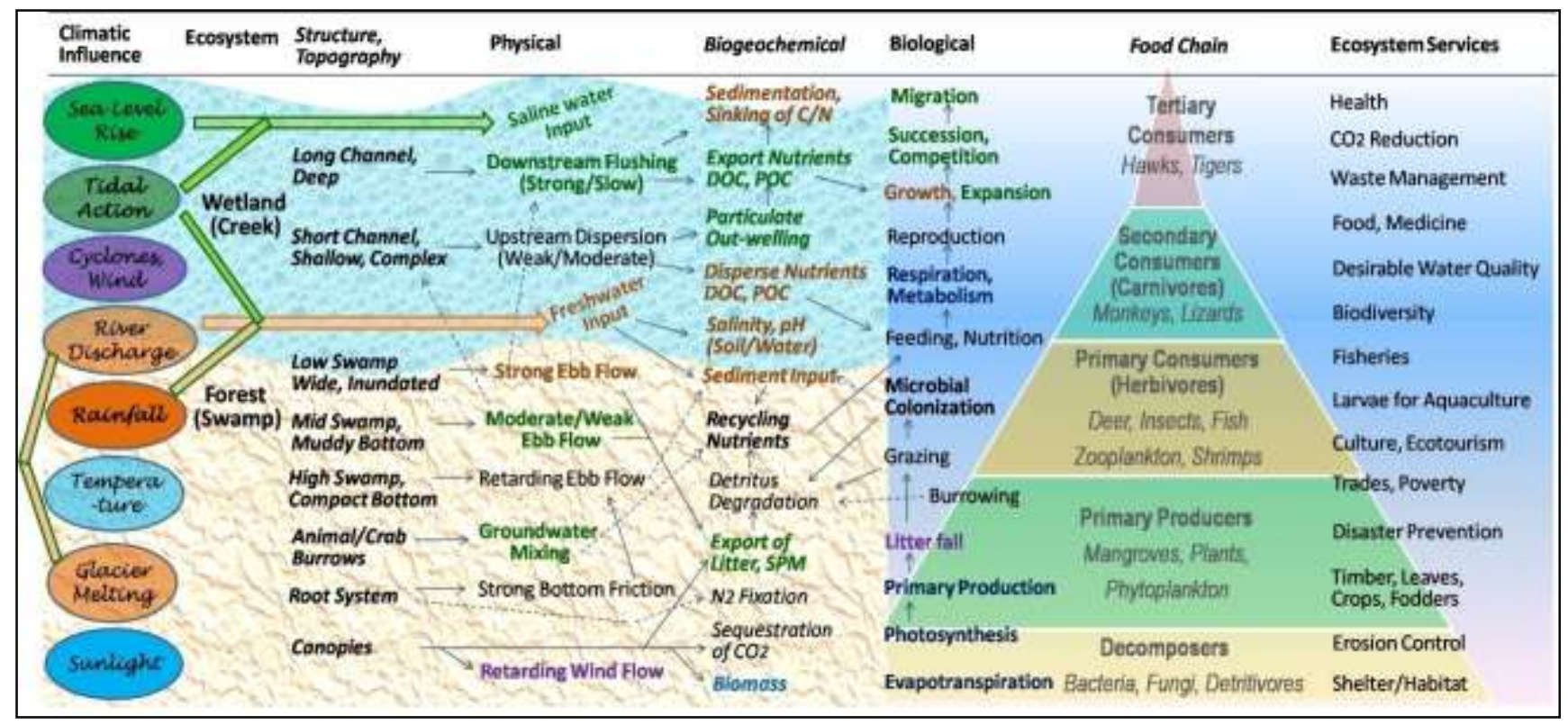

Figure 1. Interactions and influences of climatic factors on the key physical, biogeochemical, biological functions of the wetland and forest ecosystems, with reference to ecosystem services of the Sundarban mangroves. The major regulations among the ecosystem components influenced by the climatic factors have been shown by arrows. The coloured texts of individual ecosystem component matched those of the filled encircles of regulating climatic factors, e.g., green, brown, blue and violet coloured components are regulated by i) sea level rise/tide/salinity, ii) Glacier melting/rainfall/river discharge, iii) sunlight/temperature, and iv) wind/cyclones, respectively.

\subsection{ENSO}

Climatic modulations due to the El Niño Southern Oscillation (ENSO) have large impact on the monsoon rainfall variability and intensification, compounded with flooding events, and sea surface temperature increase in Southeast Asia. The decadal ENSO events, which are gradually becoming more severe, causing record 
breaking heat spells and rainfall anomalies throughout many parts of the world, will likely have severe consequences on the biodiversity and biogeochemistry of Sunderban swamps and wetlands influencing regional ecosystem functions and services. ENSO impacts on the Sunderban ecosystems are associated with large variations in the riverine discharge, estuarine sediment dynamics, and tidal regime, which eventually influence the primary production and species abundance (IPCC, 2007; Lara et al., 2011). ENSO-driven higher temperatures may severely distort population structure and cause drastic reduction or local extinction of stocks of many aquatic organisms including fishes. Extreme high temperature may inhibit growth, behaviour, reproduction of these vulnerable aquatic organisms. Additionally, the larvae and juveniles of many estuarine and marine fishes and higher organisms usually prefer to grow in the shallow micro-environments and food-rich mangrove wetlands, which may become an unsuitable due to the extreme temperature mediated changes in the primary production and nutrient availability (Kopprio et al., 2010). On the other hand the ENSO-mediated floods can endanger the species adapted to high salinity and favor the low-salinity tolerant species.

\subsection{Seasonal dynamics in physicochemical conditions}

In Sundarban wetlands, water turbidity ranges from 30-200 NTU, with higher concentration during monsoon (June-October), when silicate, phosphate, nitrate and ammonia also have higher concentrations. However, salinity, $\mathrm{pH}$, conductivity, turbidity, dissolved oxygen (DO), biochemical oxygen demand (BOD) have higher values during pre-monsoon (February-May). The post-monsoon season (Nov-Jan) is characterized in having lowest temperature, and moderate salinity, and other parameters. Sundarban estuarine water $\mathrm{pH}$ usually ranges from 7.0 - 7.5 in the upstream less saline and fresh water sections, and between 8.0 - 8.6 in the downstream high saline areas. Soil salinity, organic carbon and sediment contents usually follow their respective trends in surface water of tidal creeks or riverine channels, and vice versa (Chakraborty et al., 2009).

The flux of nutrients and organic matter from mangroves to near shore zones is controlled by a complex interplay of physical, geochemical, and biological processes. Apart from local geomorphology, the nutrient dynamics in estuarine mangroves are heavily influenced by the climatic factors including tides, salinity intrusion and sea-level rise. Temperature variation has positively correlated with dissolved nitrate and phosphate concentrations but negatively related with dissolved ammonia concentration in the Sundarban wetlands. Similarly, seasonal variations of total organic carbon (TOC) in surface water, with the lowest and highest means of 5-10 and $15-20 \mathrm{mg} \mathrm{L}^{-1}$ during post-monsoon winter and hot monsoon seasons, respectively (Hossain and Bhuiyan, 2015). During monsoon riverine input and terrestrial washed materials, including drainage waste materials from the upstream localities outside the mangroves, also contribute to increase the nutrient load in the wetlands. In Sundarban estuaries, the phosphate concentration varies from 0.4 to $1.0 \mu \mathrm{mol} \mathrm{\textrm {L } ^ { - 1 }}$, the nitrate concentration varied from 2.0 to $40 \mu \mathrm{mol} \mathrm{L}{ }^{-1}$, and silicate concentration from 4.0 to $50 \mu \mathrm{mol} \mathrm{L}{ }^{-1}$ (Lara et al., 2011). Environmental screenings have observed the Sundarban estuary as phosphorus limited during postmonsoon and nitrogen-limited in pre-monsoon and monsoon (Chakraborty et al., 2009). On the other hand, an increasing trend in ammonia and phosphate concentrations (70 to $80 \mu \mathrm{g} \mathrm{L}^{-1}$ and 300 to $1500 \mu \mathrm{g} \mathrm{L}^{-1}$, respectively) have been reported in dry winter but abruptly drops with the onset of monsoon rainfall (10 to 20 $\mu \mathrm{g} \mathrm{L}^{-1}$ and 40 to $50 \mu \mathrm{g} \mathrm{L}^{-1}$, respectfully) in the Sundarban mangrove riverine channels (Manna et al., 2010).

\subsection{Habitat modifications}

While the mangroves' areal extent has not changed much in the recent past, forest health and structure have altered substantially in many regions of the Sundarban with sharp decline in tree density and $50 \%$ reduction in forest stock. Flooding and severe cyclones, particularly in 1987-1988, 1991, 2007 and 2009, are the major shocks which have impacted on forest growth and production (Ghosh et al., 2015). Although many mangrove species are highly tolerant to environmental and natural stress associated with their intertidal habitat, reduction of freshwater input and severity in climatic disasters may greatly cause alteration of the mangrove habitats. The widespread occurrence of the "top dying" disease of mangrove plants in the Sundarban is thought to be related to increasing intrusion of saline water associated with the ongoing climate change (Rahman et al., 2010b; Figure 2). Moreover, coastal erosion and submergence due to the rising sea level are increasing the loss of mangrove habitats along the Bengal coast. Within the last decades, several islands (e.g., Lohachara) of Sundarban mangroves have been lost due to severe erosion and coastal inundation, and more than a dozen have become prone to erosion and high-tide events (Hazra et al., 2002). Increasing sediment deposition due to reduction or change in riverine flow resulting in closure of tidal creeks is another important cause of Sundarban degradation (Ghosh et al., 2015; Aziz and Paul, 2015). 


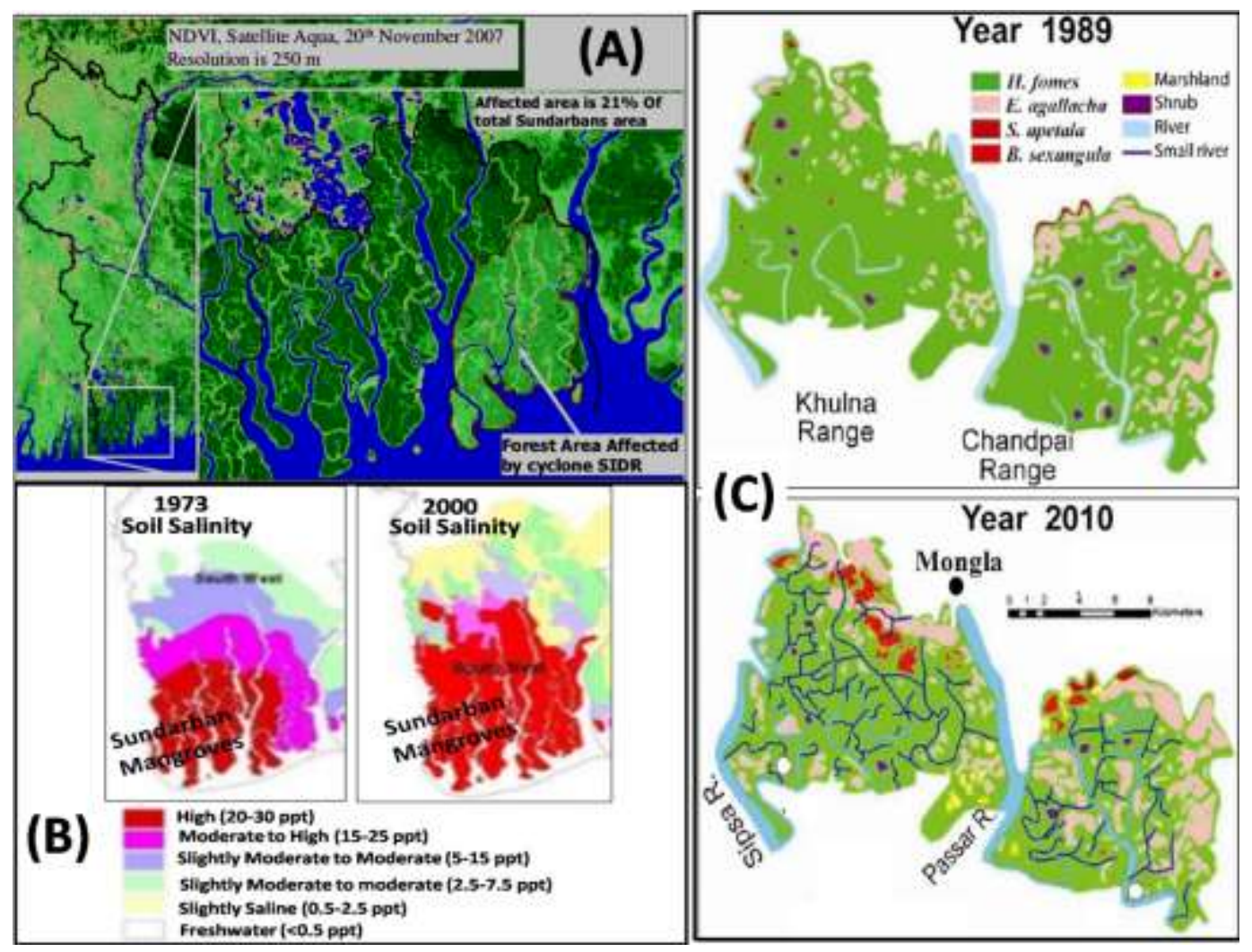

Figure 2. Observed impacts of climatic disasters on the Sundarban mangrove ecosystems. (A) Satellite images showing destruction of mangroves affecting about one-fifth area of the mangroves, (B) Differences in soil salinity between 1973 and 2010 due to climate change mediated salinity intrusion, and (C) Differences between 1989 and 2010 in the major flora in the mangrove swamp due to the impacts of increased salinity, and in morphological habitats of mangrove swamp, with formation of new marshes due to river erosion (Aziz and Paul, 2015).

\subsection{Spatio-temporal variations in primary production}

The rate and seasonality of litter fall may depend on the type of mangrove species, e.g., no seasonality in Rhizophora mangle and strong seasonality in Avicennia sp. (Lara and Dittmar, 1999). Light intensity and water temperature can influence nitrogen fixation in mangroves and the rate is higher during summer than in winter (Toledo et al., 1995). Decomposition of litter and other detritus in mangroves has climatic influences, and it is substantially faster during hot and humid weather, i.e., during the monsoon season. Also, detritus and organic carbon export rates in Sundarban mangroves show variations correlated to the seasonal fluctuations in sea level and rainfall (Twilley, 1985; Chakraborty et al., 2009).

Seasonal plankton blooms can be a major source of autochthonous production of organic carbon in mangroves (Jennerjahn and Ittekkot, 2002). Tide cycles and the onset of the monsoon season often play important roles in diurnal and seasonal variability of phytoplankton in wetlands and primary production in forests. Phytoplankton abundance usually reaches highest levels during post-monsoon and lowest levels during monsoon (Manna et al., 2010). Similarly, gross primary production and community respiration in Sundarban wetlands show lower values during the monsoon season than post-monsoon or early pre-monsoon (Saha et al., 2001). In shallow estuarine wetlands, phytoplankton blooms are linked to fluctuations in river flow, stratification of the water column, grazing pressure by zooplankton, nutrient dynamics, and light availability.

\subsection{Eutrophication induced threats}

Climate change may strengthen the effects of coastal eutrophication (Mooij et al., 2007). In the Sundarban ecosystems occurrence of eutrophic conditions have been reported during winter and pre-monsoon (Manna $e t$ al., 2010). However, availability of higher nutrient concentration, like eutrophication, may introduce instability to mangrove forests because nutrients, particularly nitrogen, stimulate growth of shoots relative to roots, thereby increasing vulnerability to water stress during dry period (Catherine et al., 2009). Enhanced instability with coastal eutrophication has far reaching consequences for many aspects of mangrove ecosystem function under contemporary and future climate conditions. Certain phytoplankton like Cyanobacteria respond more strongly to 
rising temperature than green algae and diatoms, resulting in higher growth rates and more frequent bloom events (Paerl \& Huisman, 2008). Cyanobacteria are known to be a relatively poor food item for zooplankton. The lower food quality could signify lower abundance and growth rate for the zooplankton and thus, may be detrimental to fishes (Kopprio et al., 2010). In addition to toxic effects, increasing plankton biomass can potentially also generate anoxia, with subsequent large-scale decay of phytoplankton populations, followed by microbe-mediated nutrient enrichment in coastal surface water (Manna et al., 2010).

\subsection{Impacts on biodiversity}

Rise in temperature affects the biology of a species at its molecular, physiological and biochemical levels thereby altering its distribution patterns as well as community interactions (Das et al., 2004). In mangrove wetland ecosystems the heterotrophic bacterial activities are controlled by the interaction of variety of regulatory factors, namely, temperature, inorganic nutrients, dissolved organic carbon, $\mathrm{pH}$, salinity stress, and host availability (Neogi et al., 2014). In case of nutrient rich Sunderban estuary the increase in bacterial populations often correlate with temperature rise (Manna et al., 2010). Halophilic Vibrio spp., associated with diseases in human and aquatic organisms, and methanogenic bacterial populations as well as have been shown to fluctuate with variations in temperature, $\mathrm{pH}$, redox potential, turbidity and salinity of estuarine wetland waters and swamp sediments (Mohanraju and Natarajan, 1992; Lara et al., 2011; Batabyal et al., 2014).

Changes in species composition and dominance of phytoplankton can be mediated by a variety of mechanisms including ambient temperature, light penetration, nutrient supply, and removal by zooplankton. Climatemediated variations in wetland phytoplankton, with bimodal growth pattern, a low peak in pre-monsoon (AprilMay) and other peak in post-monsoon (November-December) corresponding their highest abundance, have been reported for the Sundarban wetlands. In the estuarine creeks of this mangroves, diatoms are observed to predominate in winter, pennates in summer whereas Chlorophyceae, Cyanophyceae and Euglenoids in monsoon. However, intra-Family variations in species diversity may also happen, e.g., for diatoms, monsoon rainfall may drastically Coscinodiscus spp. but at the same time instigate Skeletonema costatum (Biswas et al. 2010; Manna et al. 2010). The zooplankton species richness is usually higher in monsoon, followed by premonsoon, and lowest in post-monsoon. Although copepods can be considered as the major group, which comprised $40 \%-65 \%$ of total zooplankton in most of the months, occasional dominance of polychaete and shrimp larvae in the Sundarban wetlands has been reported (Manna et al., 2012).

Broadly, the impacts of climate change on living organism can be differentiated into two categories, i.e., shifts in species' distribution supporting their survival, and shifts in their phenology or the timing of biological activities including reproduction. The sea level rise coupled with other global warming mediated probable future changes in physicochemical properties of both wetlands and swamp forests, e.g., salinity invasion, massive shoreline erosion, shifting of mud flats and sand dunes, increase in sediment load, temperature, tidal amplitude, and decrease in transparency, nutrients and $\mathrm{pH}$, will probably exert considerable bio-ecological stresses on Sundarban ecosystems resulting substantial changes in species composition. A salient impact of salinity intrusion on phytoplankton species diversity, with gradual increase in the abundance of $S$. costatum, comprising from $1.5 \%$ to $19.0 \%$ of total phytoplankton, during 1990 to 2007 in the Sundarban wetlands is already evident (Biswas et al., 2010). In the long run, the shift in population dynamics and species diversity of the primary producers will have profound impacts on the ecosystems food web, with probable decline in the abundance and diversity of many mangrove dependent detritivores, herbivores and other secondary consumers (Ghosh et al., 2015).

\subsection{Changes in Sundarban mangroves: impacts on human health}

The impacts of global warming affecting climate and hydrological patterns in wetland ecosystems can greatly enhance human vulnerability to waterborne diseases, especially in the low-lying coastal areas harbouring the Sundarban ecosystems (Lara et al., 2011). The survival and growth of microbial pathogens like Escherichia coli, Vibrio spp., and Salmonella spp. in aquatic environments are widely known to be regulated by climatic factors, e.g., temperature, salinity, rainfall, turbidity, and nutrients (Batabyal et al., 2014). The combination of both extended salt intrusion and higher turbidities, caused by stronger and more frequent storms and coastal erosion, could increase aquatic Vibrio pathogens, associated with cholera and gastroenteritis, in the Bengal estuaries including the Sundarban wetlands, endangering human health (Lara et al., 2009). Post-cyclone outbreaks of waterborne diarrhea, cholera, and gastroenteritis, have been frequently reported among villagers residing adjacent to the Sundarban mangroves (e.g., Bhunia and Ghosh, 2011). Various aquatic invertebrates may provide rich organic substrates to the human pathogens favoring their growth and survival. Higher incidences of most water-borne diseases, including Vibrio-related cholera, gastroenteritis and septicemia, have 
been correlated with higher populations of aquatic microinvertebrates like zooplankton (Neogi et al., 2014). Microbial nutrition supporting organic matters, including chitin, from degraded microinvertebrates usually accumulate in the suspended and benthic sediments, and re-suspension of benthic sediments by cyclones, floodings, and turbulences may enhance the growth of aquatic pathogens, posing threats of waterborne diseases to millions of coastal people around Sundarban mangroves (Lara et al., 2009; Neogi et al., 2012). Aedes mosquitoes and their larvae are principally found in the closed mangrove swamps with transient stagnant water pools due to blockage of tidal flushing. Global warming and associated increase in rainfall may induce a substantial rise in wetland mosquito populations, and subsequently the dengue outbreaks among the Sundarban dependent coastal people (Neogi et al., 2014).

\subsection{Ecosystem services supporting livelihoods and economy}

Over the years, mangroves have sustained more than 70 direct human activities. Food (e.g., fish, honey, shrimp etc), fuel wood, timber, construction and thatching materials (mangrove leaves, particularly of Nypa fruticans (Golpata), Phoenix paludosa (Hetal), bamboos, grasses), tanning materials including waxes, resins, gums, etc., plant and animal products used for cosmetics, ornaments, and decorations, and medicinal herbs were identified as important resources harvested by the communities from the mangroves (FAO, 2007; Ronnback et al., 2007). In the peripheral regions of Sunderban in Bangladesh southeast and West Bengal, millions of the people, majority acting as woodcutters and honey collectors, fishermen, and larvae catchers, are directly or indirectly dependent on these forest and wetland resources for their livelihood, food security, health and economic wellbeing (Hoq et al., 2006). In a study on Sundarban ecosystems dependent livelihood, it has been observed that about $50 \%$ of the coastal households depend directly on the forest resources for their livelihood support at varying degrees, e.g., extracting mostly fuel wood (74\%), fish (78\%) and Golpata (27\%), with an estimated value of about US\$ 1,000 per year per household (Shah and Datta, 2010). Most of the households in the villages near the mangroves collect fish that amounts between 500 to $2,500 \mathrm{~kg} \mathrm{yr}^{-1}$ per household. A variety of the Sundarban fishes are collected, mainly by forest fishers, which constitute $90 \%$ of their total fish collection. Apart from overexploitation by indiscriminate fishing, degradation of mangroves has adversely impacted natural fish stock, with 50\% reduction in fish catch in the Indus-Delta within the last couple of decades (DasGupta and Shaw, 2013). Considering some Based on valuing of some direct measurable ecosystem services supporting livelihoods, the Sundarban mangroves provide an estimated contribution of US\$277 GDP per capita (Sarwar $e t$ al., 2005). On the other hand, the indirect services of Sundarban ecosystems in terms of shoreline protection, biofiltration, carbon sequestration, and hydro-meteorological disaster risk reduction are extremely valuable, which are influenced by climatic catastrophes in increasing frequency and amplitude, affecting the livelihood and poverty level of millions of coastal inhabitants in the Bengal delta. For example, the damage to Sundarban mangroves caused by the cyclone Sidr in 2007, impacting its quarter portion, was estimated at least US\$ 140 million for the direct casualties (Rahman et al., 2010a). Moreover, this kind of natural disaster greatly hinders the coastal economy, especially, the enormously growing shrimp-based livelihoods, e.g., an estimated loss of above US\$ 200 million for the projected decline in shrimp harvests after the cyclone Sidr (Chowdhury, 2007).

\section{Discussion and Conclusions}

The structure, function and biodiversity of Sundarban forests and wetlands ecosystems, especially, the carbon and nutrient cycles, are temporally and spatially highly variable because of the multi-factorial regulations, e.g., soil type and texture, tidal range and elevation, bioturbation intensity, forest type, temperature, salinity and rainfall. Therefore, the gradual alterations in the climatic features, along with the global warming, are thought to contribute significantly in reshaping the dynamics and diversity of the Sundarban wetlands and swamp forests. For example, the predicted sea level rise causing inundation of almost one-third of the low-lying coastal region of the Bengal delta, about $2-5^{\circ} \mathrm{C}$ increase in temperature, and $>10 \%$ increase in precipitation by the end of this century (Pitchaikani et al., 2016) will most-likely cause land-ward progression and spatio-temporal alteration to the physical dimensions of the mangrove ecosystem, changes in hydro-geology, nutrient dynamics, biodiversity, including species succession and zonation pattern, primary production, and food chain related trophic regulations. In case of agriculture yields, extreme climate events, e.g., lack of sufficient water at times critical for the crop growth, less rainy days, increased intensity of rainfall events, and changes in the active/break cycles of the monsoon, have imposed severe loss in many coastal regions (Challinor et al., 2007). So far, little is known on the impacts of climatic factors on the primary production and biological yields of the Sundarban mangrove forests, although the climatic influences are likely to act similar to those of agriculture yields.

The Sundarban mangroves ecosystems contain a rich stock of mangrove biodiversity and ecologically important both locally and globally. The mangrove wetlands play a crucial role in maintaining the life cycle of 
economically important fish, shrimp, and crab species. The river-influenced and tide-dominated Sundarban ecosystems also provide seemingly invisible but vital regulatory functions for maintaining rich biodiversity and providing many ecosystem services. Because of the enormous capacity of trapping terrestrial sediments, the Sundarban ecosystems generate less turbid offshore waters, and recycle nutrients, which in turn favor the photosynthetic activity of aquatic phytoplankton, supporting organisms of higher trophic levels including shrimps and fishes. Exports of detritus and faunal biomass to offshore through tide-mediated exchange of materials support the biodiversity of offshore communities. Among other ecosystem services provided by the Sundarban include protection against floods, cyclones and storms, reduction of coastal and river bank erosion and maintenance of water quality through salinity and sediment regulation. The mangroves and wetlands are extremely important for providing vital ecosystem services or goods, such as foods, fuel woods, herbs, and ornament plants. Sundarban mangrove forests have been shown to sustain dozens of human livelihoods, ranging from fuel-wood collection to fisheries. According to an estimate, mangroves rich in nutrients like the Sundarban, can yield $>700 \mathrm{~kg} \mathrm{ha}^{-1} \mathrm{yr}^{-1}$ of fishes and crustaceans, which is more productive than extensive culture in other ecosystems, yielding $<500 \mathrm{~kg} \mathrm{ha}^{-1} \mathrm{yr}^{-1}$ (Primavera, 1991). Therefore, potential consequences of the degradation or loss of mangroves in this region are multifaceted with distinct ecological, social, and economic dimensions. Climate change mediated ecosystem alterations and subsequent loss in the availability of these goods and services can exacerbate poverty level among the mangrove-dependent populations (Shah and Datta, 2010). Recently, small-scale subsistence fishing of mud crabs in the Sundarban has turned into a fastgrowing industry, thanks to flourishing international demand, supporting thousands of families along the southwest coast of Bangladesh (Uddin et al., 2013). Even the harvested non-graded crabs are fattened at homestead, reared in captivity to increase their weight, and later sold in the market. Since the Sundarban mud crab market and its associated social issues loom large in the public consciousness, the unmonitored and unregulated collection of wild mud crabs may cause decline in their harvest. Global warming mediated hydro-climatic changes including increase in temperature, sea level, rainfall and cyclone frequency may have substantial impact on wetland ecology influencing the growth and spread of microbes, pathogenic to economically important fauna, including shrimps, crabs, and fishes, and also to humans like Vibrio spp., associated with waterborne diseases affecting millions of the coastal inhabitants. Considering the above perspectives, proper policies are invariably required that incorporates the ecohydrology framework (Figure 3), with holistic consideration of socioeconomic, ecological, and medical aspects, managing the wetlands using tools for sequestration of nutrients, regulating anthropogenic run off, etc., and applying other eco-friendly strategies to control mangrove ecosystem dynamics and thereby protect millions of the coastal people from the climate change induced increasing threats on health and livelihoods in the near future (Lara et al., 2012).

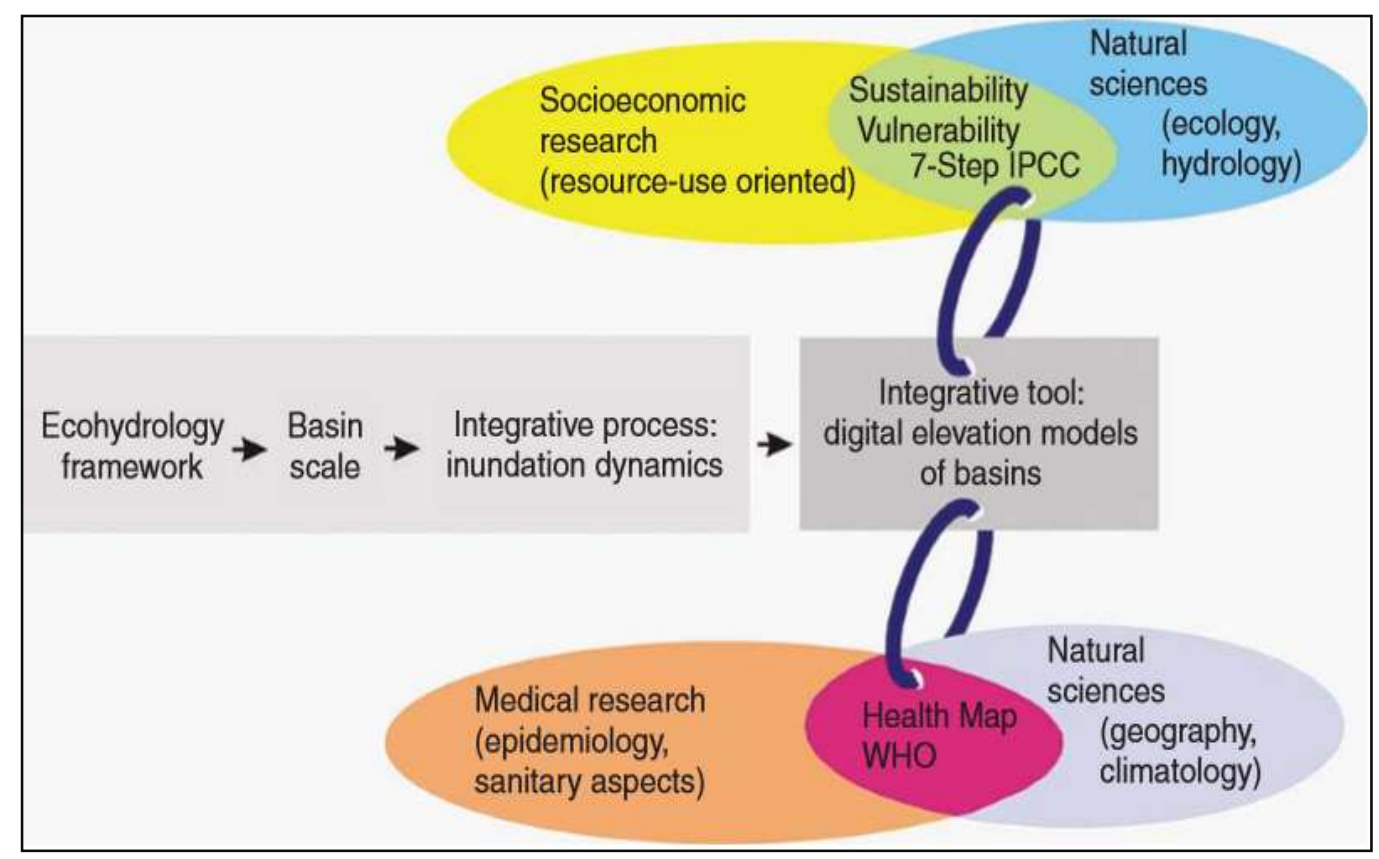

Figure 3. The ecohydrology framework, integrating socio-economic, ecological, and medical research and interventions, to formulate adaptation and mitigation strategies addressing climate change impacts on the Sundarban mangrove forests and wetlands (adapted from Lara et al., 2012). 
At the pace of current climate change, within the next few decades, a $25 \mathrm{~cm}$ rise in sea level would engulf $40 \%$, and a $45 \mathrm{~cm}$ rise by the end of the $21^{\text {st }}$ century would destroy $75 \%$ of the present dimension of Sundarban ecosystems, if no landward expansion of mangroves occurs (Colette et al., 2007). Along with this likely rise in sea level, climate change mediated increase in sea surface temperature, extremities in rainfall events, and occurrence of more cyclones in the near future (IPCC, 2007), it is highly important to promote the growth of the Sundarban mangrove forests and wetlands. Sustainable Forest Management (SFM) is a key concept that allows exploitation of the forests at a rate that maintains their biodiversity, productivity, and the regeneration capacity so that the ecosystem services are not hampered in the long run. Coastal zoning and integrated coastal zone management (ICZM) approach, coordinated through a "bottom-up" approach, is another very important aspect of mangrove management. For climate-smart conservation, the following measures are especially required to be considered: (I) protect the vulnerable spaces and species at risks, by reducing non-climate stresses (e.g., anthropogenic habitat modifications and pollutions), (II) apply adaptive management, e.g., ecohydrological tools to prevent reduction in freshwater inflow, and ensure appropriate hydro-geological regimes and water quality, (III) protect the important mangrove pockets used to refuge valuable species, afforestation and other measures to restore coastal vegetation, and (IV) reduce the rate and extent of climate change enhancing anthropogenic factors through adoption of low carbon generating pathways (Hansen et al., 2010). In the above perspectives, holistic GIS-based analyses, with different spatio-temporal scenarios of sea-level rise, high resolution (submeter) elevation data, and land-use patterns, would enable multi-dimensional considerations to identify Sundarban habitat vulnerabilities to various climatic regimes. While the Sundarban mangroves are periodically embracing climatic catastrophes in increasing manner, it is important to formulate development plans integrating conservation and climate change adaptation strategies. Therefore, in parallel to habitat protection measures, e.g., construction of bio-embankments and intervention of sediment flow to resist coastal erosion, promotion of sustainable alternative livelihoods, e.g., home gardening, mangrove-based cottage industries, bee keeping, poultry farming and ecotourism, is imperative to support the Sundarban-dependent coastal populations. Systematic interdisciplinary collaborations including natural and social scientists, community members and policy makers would enable implementing holistic adaptation and mitigation strategies to address the yet appalling future impacts of climate change to Sunderban mangrove forests and wetlands, and sustain the important biodiversity hotspots and invaluable ecosystem services.

\section{Acknowledgements}

The authors gratefully acknowledge the continuous supports of Leibniz Center for Tropical Marine Ecology (ZMT), Bremen, Germany, and Osaka Prefecture University, Japan. The thoughtful suggestions received from Prodyot Kumar Basu Neogi, ex-scientist of icddr,b, are gratefully remembered.

\section{Conflict of interest}

None to declare.

\section{References}

Alongi DM, KG Boto and F Tirendi, 1993. Effect of exported mangrove litter on bacterial productivity and dissolved organic carbon fluxes in adjacent tropical nearshore sediments. Mar. Ecol. Prog. Ser., 56: 133-144.

Alongi DM, A Sasekumar, F Tirendi and P Dixon, 1998. The influence of stand age on benthic decomposition and recycling of organic matter in managed mangrove forests of Malysia. J. Exp. Mar. Biol. Ecol., 225: 197218.

Alongi DM, G Wattayakorn, J Pfitzner, F Tirendi, I Zagorskis, GJ Brunskill, A Davidson and BF Clough, 2001. Organic carbon accumulation and metabolic pathways in sediments of mangrove forests in southern Thailand. Mar. Geo., 179: 85-103.

Aziz A and AR Paul, 2015. Bangladesh Sundarbans: Present Status of the Environment and Biota. Diversity, 7: 242-269.

Bano N., M-U Nisa, N Khan, M. Saleem, PJ Harrison, SI Ahmed and F Azam, 1997. Significance of bacteria in the flux of organic matter in the tidal creeks of the mangrove ecosystem of the Indus river delta, Pakistan. Mar. Ecol. Prog. Ser., 157: 1-12.

Batabyal, P, MH Einsporn, S Mookerjee, A Palit, SB Neogi, GB Nair and RJ Lara, 2014. Influence of hydrologic and anthropogenic factors on the abundance variability of enteropathogens in the Ganges estuary, a cholera endemic region. Sci. Tot. Environ. 472: 154-161. 
Benner R, ER Peele and RE Hodson, 1986. Microbial utilization of dissolved organic matter from leaves of the red mangrove, Rhizophora mangle, in the Fresh Creek Estuary, Bahamas. Estuar. Coast. Shelf Sci.. 23: 607619.

Bhunia R and S Ghosh, 2011. Waterborne cholera outbreak following Cyclone Aila in Sundarban area of West Bengal, India, 2009. Trans. R. Soc. Trop. Med. Hyg., 105: 214-19.

Biddanda B, S Opsahl and R Benner, 1994. Plankton respiration and carbon flux through bacterioplankton on the Lousiana shelf. Limnol. Oceanogr., 39: 1259-1275.

Biswas H, M Dey, D Ganguly, TK De, S Ghosh and TK Jan, 2010. Comparative Analysis of Phytoplankton Composition and Abundance over a Two-Decade Period at the Land-Ocean Boundary of a Tropical Mangrove Ecosystem. Estuar. Coasts, 33: 384-394.

Camilleri JC and G Ribi, 1986. Leaching of dissolved organic carbon (DOC) from dead leaves, formation of flakes from DOC, and feeding on flakes by crustaceans in mangroves. Mar. Ecol. Prog. Ser., 50: 151-160.

Catherine EL, CB Marilyn, CM Katherine and IC Feller, 2009. Nutrient Enrichment Increases Mortality of Mangroves. PLoS ONE, 4(5): e5600.

Challinor A, T Wheeler, C Garforth, P Craufurd and A Kassam, 2007. Assessing the vulnerability of food crop systems in Africa to climate change. Climate Change, 83: 381-99.

Chakraborty SK, S Giri, G Chakravarty and N Bhattacharya, 2009. Impact of eco-restoration on the biodiversity of Sundarbans Mangrove Ecosystem, India. Water Air Soil Poll. Foc., 9: 303-320.

Chakraborty SK, 2011. Mangrove Ecosystem of Sundarbans, India: Biodiversity, Ecology, Threats and Conservation. In Mangroves: Ecology, Biology and Taxonomy. Ed. Metras JN: NOVA publisher, USA, pp. 83-112.

Chowdhury MSN, MS Hossain, A Mitra and P Barua, 2011. Environmental functions of the Teknaf Peninsula mangroves of Bangladesh to communicate the values of goods and services. Mesopot. J. Mar. Sci., 26: 7997.

Chaudhury MA, 2008. Situation Analysis of Ecosystem Services and Poverty Linkages in Bangladesh. BRAC, Dhaka, pp 203. http://r4d.dfid.gov.uk/pdf/outputs/envres/india-annexb-countryreports.pdf

Colette A, (lead author), 2007. Case Studies of Climate Change and World Heritage. UNESCO, Paris, pp 82.

Davis SE (III), JW Childers (Jr.), DT Rudnick and FH Sklar, 2001. Nutrient dynamics in vegetated and unvegetated areas of a southern Everglades mangrove creek. Estuar. Coast. Shelf Sci., 52: 753-765.

Dawes C, K Siar and D Marlett, 1999. Mangrove structure, litter and macroalgal productivity in a north-most forest of Florida. Mang. Salt Marsh., 3: 259-267.

Day JW, RH Day, MT Barreiro, F Ley-lou and CJ Madden, 1982. Primary production in the Laguna de Terminos, Mexico. Aqua. Bot., 27: 267-284.

Day J.W., WH Conner, F Ley-Lou, RH Day and AM Navarro, 1987. The productivity and composition of mangrove forests, Laguna de Terminos, Mexico. Aquat. Bot., 27: 267-284

FAO (2007) The World's Mangrove 1980-2005. FAO Forestry paper 153: Rome, Italy. pp-9.

Feldpausch TR, OL Phillips, RJW Brienen, E Gloor, J Lloyd., et al., 2016. Amazon forest response to repeated droughts, Global Biogeochem. Cycles, 30, doi:10.1002/2015GB005133.

Ganguly D, A Mukhopadhyay, RK Pandey and D Mitra, 2006. Geomorphological study of Sundarban deltaic estuary. J. Indian Soc. Remote Sens., 34: 431-435.

Ghosh A, S Schmidt, T Fickert and M Nüsser, 2015. The Indian Sundarban Mangrove Forests: History, Utilization, Conservation Strategies and Local Perception. Diversity, 7: 149-169.

Golbuu Y, S Victoria, E Wolanski and RH Richmond, 2003. Trapping of fine sediment in a semi-enclosed bay, Palau, Micronesia. Estuar. Coast. Shelf Sci., 57: 941-949.

Hanebuth TJJ, HR Kudrass, J Linstädter, B Islam and AM Zander, 2013. Rapid coastal subsidence in the central Ganges-Brahmaputra Delta (Bangladesh) since the 17th century deduced from submerged saltproducing kilns. Geology, 41: 987-990.

Hansen L, J Hoffman, C Drews and E Mielbrecht, 2010. Designing Climate-Smart Conservation: Guidance and Case Studies. Conserv. Biol., 24: 63-69.

Haq ME, ML Islam, HK Paul and SH Ahmed, 2002. Decomposition and Seasonal Changes in Nutrient Constituents of Mangrove Litter of Sundarban Mangroves, Bangladesh. Ind. J. Marine Sci., 31: 130-135.

Hazra S, T Ghosh, R DasGupta and G Sen, 2002. Sea level and associated changes in the Sundarbans. Sci. Culture, 68: 309-321.

Hoq ME, MA Wahab and MN Islam, 2006. Hydrographic status of Sundarbans mangrove, Bangladesh with special reference to post-larvae and juveniles fish and shrimp abundance. Wetl. Ecol. Manage., 14: 79-93. 
Hossain GM and MAH Bhuiyan, 2015. Spatial and Temporal Variations of Organic Matter Contents and Potential Sediment Nutrient Index in the Sundarbans Mangrove Forest, Bangladesh. KSCE J. Civil Eng., DOI 10.1007/s12205-015-0333-0.

Hossain MS, JA Dearing, MM Rahman and M Salehin, 2016. Recent changes in ecosystem services and human well-being in the Bangladesh coastal zone. Reg. Environ. Change, 16: 429-443.

Hussain Z and G Acharya, 1994. Mangrove of the Sundarbans, Bangladesh, Vol. 2. IUCN-Bangkok, Dyna Print Limited, pp.1-232.

IWM, 2003. Sundarbans biodiversity conservation project-Surface water modeling. Final Report, Vol. 1. IWM (Institute of Water Management), Dhaka, Bangladesh. TA No. 3158-BAN (Contact COCS/00-696).

Jennerjahn TC and V Ittekkot, 2002. Relevance of mangroves for the production and deposition of organic matter along tropical continental margins. Naturwissenschaften, 89: 23-30.

Khan MNI, R Suwa and A Hagihara, 2007. Carbon and nitrogen pools in a mangrove stand of Kandelia obovata (S., L.) Yong: vertical distribution in the soil-vegetation system. Wetl. Ecol. Manage., 15: 141-153

Kopprio GA, RH Freije, CA Strussmann, G Kattner, MS Hoffmeyer, CA Popovich and RJ Lara, 2010. Vulnerability of pejerrey Odontesthes bonariensis populations to climate change in pampean lakes of Argentina. J. Fish Biol., 77: 1856-1866

Kristensen E, M Holmer and N Bussarawit, 1991. Benthic metabolism and sulfate reduction in a southeast Asian mangrove swamp. Mar. Ecol. Progr. Ser., 73: 93-103.

Kristensen E, S Bouillon, T Dittmar and C Marchand, 2008. Organic carbon dynamics in mangrove ecosystems: A review. Aquat. Bot., 89: 201-219.

Lara RJ and T Dittmar, 1999. Nutrient dynamics in a mangrove creek (North Brazil) during the dry season. Mang. Salt Marsh, 3: 185-195.

Lara RJ, SB Neogi, MS Islam, ZH Mahmud, S Yamasaki and GB Nair, 2009. Influence of catastrophic climatic events and human waste on Vibrio distribution in the Karnaphuli estuary, Bangladesh. Ecohealth, 6: 279-286.

Lara RJ, SB Neogi, MS Islam, ZH Mahmud, S Islam, D Paul, BB Demoz, S Yamasaki, GB Nair and G Kattner, 2011. Vibrio cholerae in waters of the Sunderban mangrove: relationship with biogeochemical parameters and chitin in seston size fractions. Wetl. Ecol. Manage, 19: 109-119.

Lara RJ, MS Islam, S Yamasaki, SB Neogi, GB Nair, 2012. Aquatic ecosystems, human health, and ecohydrology. In Treatise on Estuarine and Coastal Science, Vol. 10, Section 15, Eds. McLusky D and E Wolanski: Academic Press Elsevier Inc., USA. pp. 1-33.

Manna S, K Chaudhuri, S Bhattacharyya and M Bhattacharyya, 2010. Dynamics of Sunderbans estuarine ecosystem: eutrophication induced threat to mangroves. Saline Systems, 6:8.

Manna S, K Chaudhuri, KS Sarma, P Naskar, S Bhattacharyya and M Bhattacharyya, 2012. Interplay of Physical, Chemical and Biological Components In Estuarine Ecosystem with Special Reference to Sundarbans, India. In Ecological Water Quality - Water Treatment and Reuse, Ed., D. Voudouris, ISBN: 978-953-51-0508-4.

Mitra A and K Banerjee, 2004. Focus Indian Sundarbans. In Living Resources of the Sea, Ed., Banerjee SR, WWF India: Canning Field Office, 24 Parganas (S), West Bengal, pp. 96.

Mitra A and K Banerjee, 2011. Trace elements in edible shellfish species from the lower Gangetic delta. Ecotoxicol. Environ. Saf., 74: 1512-1517.

Mohanraju R and R Natarajan, 1992. Methanogenic bacteria in mangrove sediments. Hydrobiologia, 247: 187193.

Mooij WM, JH Janse, LN De Senerpont Domis, S Hulsmann and B. W Ibelings, 2007. Predicting the effect of climate change on temperate shallow lakes with the ecosystem model PC Lake. Hydrobiologia, 584: 443454.

Morgan JP and WG McIntire, 1959. Quaternary Geology of the Bengal Basin, East Pakistan and Burma. Bull. Geo. Sci. Am., 70: 319-342.

Neogi SB, MS Islam, GB Nair, S Yamasaki and R Lara, 2012. Occurrence and distribution of planktonassociated and free-living toxigenic Vibrio cholerae in a tropical estuary of a cholera endemic zone. Wetl. Ecol. Manage, 20: 271-285.

Neogi SB, S Yamasaki, M Alam and RJ Lara, 2014. The role of wetland microinvertebrates in spreading human diseases. Wetl. Ecol. .Manage., 22: 469-491.

Oliver, J. 1982. The geographic and environmental aspects of mangrove communities: Climate. In: Mangrove ecosystems in Australia, Ed., Clough BF, Australian National University Press, Canberra, pp. 19-30.

Ovalle ARC, CE Rezende, LD Lacerda and CAR Silva, 1990. Factors affecting the hydrochemistry of a mangrove tidal creek, Sepetiba Bay, Brazil. Estuar. Coast. Shelf Sci., 31: 639-650 
Paerl HW and J Huisman, 2008. Blooms like it hot. Science, 320: 57-58.

Perry AL, PJ Low, JR Ellis and JD Reynolds, 2005. Climate change and distribution shifts in marine fishes. Science, 308: 1912-1915.

Pitchaikani JS, KS Sarma and S Bhattacharyya. First time report on the weather patterns over the Sundarban mangrove forest, East Coast of India. https://www.researchgate.net/publication/282867219 DOI: 10.13140/RG.2.1.3089.2249

Primavera JH, 1991. Marine Shrimp Culture: Principles and Practices, 23: 701 - 728.

Raha A, S Das, K Banerjee and A Mitra, 2012. Climate change impacts on Indian Sunderbans: A time series analysis (1924-2008). Biodivers. Conserv., 21: 1289-1307.

Rahman MR and M Asaduzzaman, 2010. Ecology of Sundarban, Bangladesh. J. Sci. Foundation, 8(1\&2): 3547.

Rahman MM, MNI Khan, AKF Hoque and I Ahmed, 2015. Carbon stock in the Sundarbans mangrove forest: spatial variations in vegetation types and salinity zones. Wetl. Ecol. Manage, 23: 269-28.

Rahman MM, MM Rahman and KS Islam, 2010. The causes of deterioration of Sundarban mangrove forest ecosystem of Bangladesh: conservation and sustainable management issues. AACL Bioflux, 3(2), http://www.bioflux.com.ro/aacl.

Rivera-Monroy VH, JW Day, RR Twilley, F Vera-Herrera and CC Molina, 1995. Flux of nitrogen and sediment in a fringe mangrove forest in Terminos Lagoon, Mexico. Estuar. Coast. Shelf Sci., 40: 139-160.

Robertson AI and NC Duke, 1990. Mangrove fish communities in tropical Australia: spatial and temporal patterns in densities, biomass and community structure. Mar. Biol., 104: 369-79.

Robertson AI, 1991. Plant-animal interactions and the structure and function of mangrove forest ecosystem. Austr. J. Ecol., 16: 433-443.

Robertson AI, DM Alongi and KG Boto, 1992. Food chains and carbon fluxes. In Tropical Mangrove Ecosystems- Coastal and Estuarine Series 41, Eds., Robertson AI and DM Alongi, American Geophysical Union, Washington, pp. 293-326.

Raghukumar S, V Sathe-Pathak, S Sharma and C Raghukumar, 1995. Thraustochytrid and fungal component of marine detritus. III. Field studies on decomposition of leaves of the mangrove Rhizophora apiculata. Aquat. Microb. Ecol., 9: 117-125.

Ronnback P, B Crona and L Ingwall, 2007. The return of ecosystem goods and services in replanted mangrove forests: perspectives from local communities in Kenya. J. Environ. Conserv., 34: 313-324.

Routray TK, GC Satapathy and AK Mishra, 1996. Seasonal fluctuation of soil nitrogen transforming microorganisms in Bhitarkanika mangrove forest. J. Environ. Biol., 17: 325-330.

Saha SB, SB Bhattacharyya and A Choudhruy, 2001. Photosynthetic activity in relation to hydrobiological characteristics of a brackishwater tidal ecosystem of Sundarbans in West Bengal, India. Tropical Ecol., 42: 111-115.

Sarker S, KC Kuri, MS Chowdhury and M Toufiqur, 2010. Mangrove: A livelihood option for coastal community of Bangladesh. Bangl. Res. Pub. J., 3: 1187-1192.

Sengupta A and S Chaudhury, 1991. Ecology of heterotrophic dinitrogen fixation in the rhizosphere of mangrove plant community at the Ganges river estuary in India. Oecologia, 87: 560-564.

Shah MAR and DK Datta, 2010. A quantitative analysis of mangrove forest resource utilization by the dependent livelihoods. ISEE conference on Advancing Sustainability in a Time of Crisis, August 22-25, Oldenburg-Bremen, Germany.

Shams-Uddin M, MAR Shah, S Khanoma and MK Nesha, 2013. Climate change impacts on the Sundarbans mangrove ecosystem services and dependent livelihoods in Bangladesh. Asian J. Conserv. Biol., 2: 152-156.

Sherman RE, TJ Fahey and RW Howarth, 1998. Soil-plant interactions in a neotropical mangrove forest: iron, phosphorus and sulfur dynamics. Oecologia, 115: 553-563.

Silva CAR, LD Lacerda, AR Ovalle and CE Rezende, 1998a. The dynamics of heavy metals through litterfall and decomposition in a red mangrove forest. Mangroves and Salt Marshes, 2: 149-157.

Silva CAR, AA Mozeto and ARC Ovalle, 1998b. Distribution and fluxes as macrodetritus of phosphorus in red mangroves, Sepetiba Bay, Brazil. Mang. Salt Marsh., 2: 37-42.

Singh OP, 2002. International variability and predictability of sea level along the Indian coast. Theor. Appl. Climatol., 72: 11-28.

Spalding, M Kainuma and L Collins, 2010. World Atlas of Mangroves. Earthscan, London, UK, 2010; pp. 319.

Thibodeau FR and NH Nickerson, 1986. Differential oxidation of mangrove substrate by Avicenia germinans and Rhizophora mangle. Am. J. Bot., 73: 512-516. 
Thong KL, A Sasekumar and N Marshall, 1993. Nitrogen concentrations in a mangrove creek with a large tidal range, Peninsular Malaysia. Hydrobiologia, 254: 125-132.

Toledo G, Y Bashan and A Soeldner, 1995. Cyanobacteria and black mangroves in Northeastern Mexico: colonization, and diurnal and seasonal nitrogen fixation on aerial roots. Can. J. Microbiol., 41: 999-1011.

Twilley RR, RH Chen and T Hargis, 1992. Carbon sinks in mangroves and their implications to carbon budget of tropical coastal ecosystems. Water, Air and Soil Pollution, 64: 265-288.

Twilley RR, M Pozo, VH Garcia, V.H Rivera-Monroy, R Zambrano and A Bodero, 1997. Litter dynamics in riverine mangrove forests in the Guayas River estuary, Ecuador. Oecologia, 111:109-122.

Twilley RR, 1998. Mangrove wetlands. In Southern Forested Wetlands: Ecology and Management, Eds., Messina MG and WH Conner: Lewis Publishers, New York, pp. 445-473.

Uddin MS, ED van Steveninck, M Stuip and MA Shah, 2013. Economic valuation of provisioning and cultural services of a protected mangrove ecosystem: a case study on Sundarbans Reserve Forest, Bangladesh. Ecosystem Services, 5: 88-93.

Unnikrishnan, AS, MRR Kumar and B Sindhu, 2011. Tropical cyclones in the Bay of Bengal and extreme sealevel projections along the east coast of India in a future climate scenario. Curr. Sci. India, 101: 327-331.

van der Valk AG and PM Attiwill, 1984. Acetylene reduction in an Avicennia marina community in Southern Australia. Aust. J. Bot., 32: 157-164.

Vazquez P, G Holguin, ME Puente, A Lopez-Cortes and Y Bashan, 2000. Phosphate-solubilizing microorganisms associated with the rhizosphere of mangroves in a semiarid coastal lagoon. Biol. Fertil. Soils, 30: 460-468.

Wahid SM, SB Mukand and AR Bhuiyan, 2007. Hydrologic monitoring and analysis in the Sundarbans mangrove ecosystem, Bangladesh. J. Hydrol., 332: 381-395.

Walters BB, P Rönnbäck, JM Kovacs, B Crona, SA Hussain, R Badola, JH Primavera, E Barbier and F Dahdouh-Guebas, 2008. Ethnobiology, socio-economics and management of mangrove forests: A review. Aquat. Bot., 89: 220-236.

Wolanski E and P Ridd, 1990. Mixing and trapping in Australian tropical coastal waters. In Residual current and long term transport, Ed. RT Cheng: Springer Verlag, NY, pp. 165-183.

Zaman S, SB Bhattacharyya, P Pramanick, AK Raha, S Chakraborty and A Mitra, 2013. Rising water salinity: A threat to mangroves of Indian Sundarbans. In Water Insecurity: A Social Dilemma; Eds., Abedin MA, U Habiba and R Shaw: Emerald Group Publishing Ltd., Bingley, UK, pp. 167-183. 